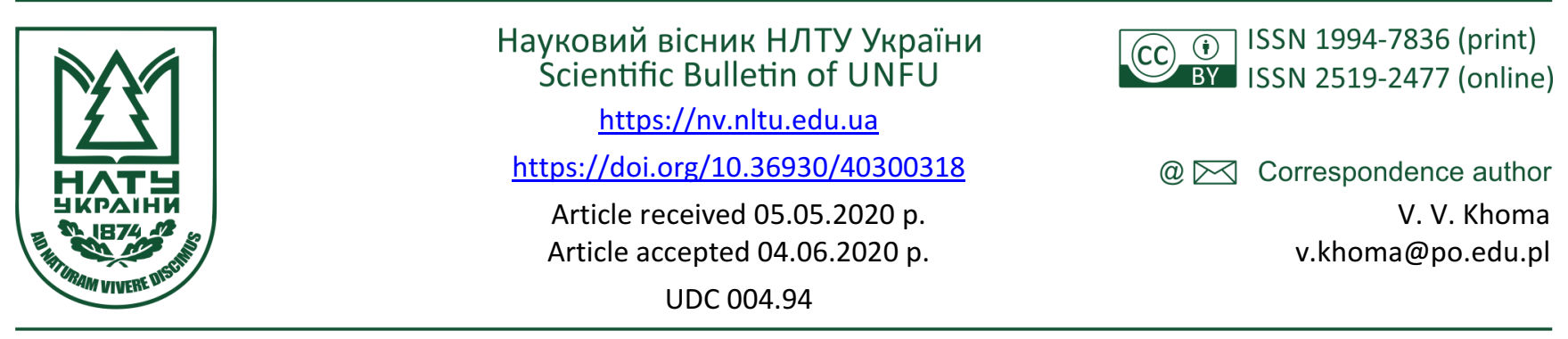

Ю. В. Хома ${ }^{1}$ В. В. Хома ${ }^{1,2}$, Д. В. Сабодашко ${ }^{1}$, Су Юн

${ }^{1}$ Національний університет "Львівська політехніка", м. Львів, Украӥна

${ }^{2}$ Політехніка Опольська, м. Ополе, Польща

${ }^{3}$ Хубейський технологічний університет, м. Хубей, КНР

\title{
АНАЛІЗ ЕФЕКТИВНОСТІ МЕТОДІВ КОРИГУВАННЯ ПРОМАХІВ У СИСТЕМАХ БІОМЕТРИЧНОЇ ІДЕНТИФІКАЦІЇ НА ПІДСТАВІ ЕЛЕКТРОКАРДІОГРАМИ
}

Здійснено порівняння ефективності різних методів коригування промахів у біометричних системах ідентифікації. Основна ідея - виявити сегменти ЕКГ-сигналу із промахами, і замість їх вилучення з процесу ідентифікації, застосувати процедуру їх коригування. Це дасть змогу отримати більший обсяг даних і кращу статистичну базу для навчання та калібрування системи. У роботі порівнювали три різні методи усунення промахів. Перший метод базується на оцінюванні статистичного відхилення вибірок від певного номінального значення на деякий поріг. При цьому аналізується не весь сигнал одразу, а тільки його частина в межах ковзного вікна. В основі двох інших методів знаходиться ідея застосування штучних нейронних мереж, зокрема одного із їх різновидів - автоенкодерів. Відмінність між методами із використанням автоенкодерів полягає у такому: в одному випадку теж використовується ковзне вікно, що дає змогу безпосередньо задавати критерії, за якими відбувається коригування, водночас як за іншим методом виконується коригування за критеріями, які система підбирає автоматично на етапі навчання. Окрім цього, в роботі описано структуру системи біометричної ідентифікації на підставі сигналу електрокардіограми. До ключових структурних компонентів системи належать: аналоговий вимірювальний блок, АЦП та низка цифрових функціональних блоків для перетворення та аналізу сигналів. Ці блоки можуть бути імплементовані на різних обчислювальних платформах, таких як мікроконтролери, ПК, хмарні сервіси). Ці цифрові блоки виконують такі перетворення, як: низькочастотна та високочастотна фільтрація, виявлення R-піків у сигналі електрокардіограми, сегментація серцевих циклів, нормалізація за амплітудою, усунення аномалій, зменшення розмірності та класифікація. Експерименти проводили на самостійно зібраному наборі даних LBDS (Lviv Biometric Dataset). Ця база даних на момент написання статті містила понад 1400 записів для 95 різних осіб. Базова похибка ідентифікації без коригування промахів становить близько $14 \%$. Після застосування процедури коригування промахів похибка ідентифікації зменшилась до $2,0 \%$ для алгоритмів на підставі автоенкодерів та до 2,9\% для алгоритмів на підставі статистичних методів. При цьому найкращі результати було досягнуто за використання LDA класифікатора у поєднанні з РCA-компресією $(1,7 \%)$, а також для KNN класифікатора без РСА-компресії (2,3\%). Проте додавання процедури коригування промахів у процес біометричної ідентифікації призводить до певного збільшення часу на опрацювання сигналу (до 20 \%), що однак не критично для більшості прикладних застосувань.

Ключові слова: біометрика; ідентифікація людини; сигнал ЕКГ; автоенкодери; машинне навчання; виявлення аномалій.

\section{Вступ}

Метрологія має важливе значення для прогресу в таких галузях, як: наука і техніка $[18,24,33]$, екологія [27], медицина [21], але останнім часом також застосовується в економіці [6], криміналістиці [10] та кібербезпеці [5]. У сучасній метрології спостерігається стійка тенденція до використання технологій машинного навчання для вдосконалення метрологічних характеристик засобів вимірювальної техніки, включаючи підвищення точності вимірювань $[12,31]$. Це сприяє помітному прогресу в розробленні нових метрологічних процедур $[13,14,29]$, у характеризації нових матеріалів або процесів, коли немає довідкового джерела, наприклад, використовуючи такий новий біомаркер, як електрокардіограма (ЕКГ) у системах автентифікації [26].

Особливістю підходів, пов'язаних із машинним навчанням, $\epsilon$ побудова і використання неформальних моделей, які будуються на підставі опрацювання й аналізу нагромаджених даних. Тому важливо забезпечити реле-

\section{Інформація про авторів:}

Хома Юрій Володимирович, канд. техн. наук, ст. викладач, кафедра інформаційно-вимірювальних технологій. Email: khoma.yuriy@gmail.com; https://orcid.org/0000-0002-4677-5392

Хома Володимир Васильович, д-р техн. наук, професор, інститут автоматики. Email: v.khoma@po.edu.pl; https://orcid.org/0000-0001-9391-6525

Су Юн, PhD, Associate Professor (доцент), кафедра комп'ютерних наук. Email: sjhosix@gmail.com

Кочан Орест Володимирович, канд. техн. наук, доцент, кафедра комп'ютерних наук. Email: orestvk@gmail.com; https://orcid.org/0000-0002-3164-3821

Цитування за ДСту: Хома Ю. В., Хома В. В., Сабодашко Д. В., Су Юн, Кочан О. В. Аналіз ефективності методів коригування промахів у системах біометричної ідентифікації на підставі електрокардіограми. Науковий вісник НлтУ України. 2020, т. 30, № 3. C. 99-105.

Citation APA: Khoma, Yu. V., Khoma, V. V., Su Jun, \& Kochan, O. V. (2020). Analysis of efficiency of the outliers correction methods for systems of biometric identification based on electrocardiogram. Scientific Bulletin of UNFU, 30(3), 99-105. https://doi.org/10.36930/40300318 
вантність даних, як на етапі навчання, так і в робочому режимі. Для зменшення спотворень у медичній діагностиці застосовують запис електрокардіограми за 12 стандартними відведеннями, коли пацієнт зручно лежить на кушетці, затомовуючи дихання у моменти запису. Очевидно, що такий спосіб є занадто складний і неприйнятний для систем біометричної автентифікації. У таких системах застосовують максимально простий і зручний зйом ЕКГ-сигналу з пальців лівої і правої рук, що різко збільшує рівень завад і спотворень. Навіть після застосувань класичних прийомів знешумлення сигналів у ЕКГ-записах залишаються промахи (англ. Outliers), тобто аномальні відхилення окремих фрагментів у записі електрокардіограми. Найчастіше причиною промахів $€$ артефакти дихання або тимчасова втрата контактів під час зйому біопотенціалів.

На цей час розроблено різні методи, спрямовані на виявлення промахів у ЕКГ-записах. Проте у відомих підходах виявлення промахів $є$ підставою для усунення цілих сегментів ЕКГ-сигналу, що відповідають окремим серцевим циклам, навіть якщо до промахів зараховано всього декілька вибірок оцифрованого сигналу. Автори пропонують не відкидати сегменти, у яких виявлено вибірки із аномальними відхиленнями, а виконувати їх коригування за певними правилами. Перевагою такого підходу є збереження обсягу даних, що важливо для надійної роботи класифікаторів, які використовують алгоритми машинного навчання. Коригування промахів є особливо актуальним у реальних системах біометричної автентифікації, коли з міркувань зручності відбір ЕКГ-сигналу здійснюється із пальців лівої і правої руки, а рівень спотворень $є$ значно вищим порівняно із стандартним варіантом реєстрації електрокардіограм, що застосовується у медичній діагностиці. Окрім цього, застосування процедури коригування промахів позитивно позначається на скороченні тривалості відбору ЕКГ-сигналів.

Об'єктом дослідження є автентифікація користувачів на підставі комп'ютерного опрацювання та евристичного аналізу їх електрокардіограм.

Предметом дослідження є методи і засоби виявлення та коригування промахів ЕКГ-сигналів у системах біометричної ідентифікації, що дасть змогу отримати більший обсяг даних і кращу статистичну базу для навчання та калібрування системи.

Мета дослідження - проаналізувати методи виявлення та коригування промахів у ЕКГ-записах, а також дослідити їх впливу на точність біометричної ідентифікації суб'єктів.

Для досягнення зазначеної мети потрібно виконати такі основні завдання дослідження:

- охарактеризувати аномалії у записах електрокардіограми;

- провести порівняльний аналіз відомих методів виявлення та коригування промахів у ЕКГ-сигналах;

- подати новий підхід до виявлення та коригування аномальних відхилень у ЕКГ-сегментах, який базується на застосуванні нейромережевих автоенкодерів;

- описати систему біометричної ідентифікації суб'єктів за їхніми ЕКГ-записами, яку автори використали для експериментальних досліджень;

- проаналізувати результати експериментів і зробити висновки щодо точності ідентифікації суб'єктів за застосування різних методів виявлення та коригування промахів та алгоритмів машинного навчання.

Наукова новизна результатів дослідження полягає в тому, що вперше розроблено метод виявлення та кори- гування промахів у ЕКГ-записах, який базується на застосуванні нейромережевого автоенкодера. Також новими $\epsilon$ результати порівняльного аналізу із двома іншими методами, причому ефективність методів оцінюється за критерієм точності автентифікації суб'єктів за допомогою різних алгоритмів машинного навчання.

Практична значущість отриманих результатів дослідження полягає у тому, що розроблений метод можна використати для коригування аномальних відхилень у записах електрокардіограм, що робить можливим застосування простого і зручного відбору ЕКГ-сигналів із пальців рук, а також сприяє скороченню тривалості реєстрації користувачів у системі біометричної автентифікації.

Аналіз літературних джсерел. У біометриці застосовують автоматизовані методи і засоби ідентифікації людини, які засновані на деяких унікальних біологічних характеристиках особи - біометричних маркерах. Такі біомаркери, зазвичай, об'єднані у класи: фізіологічні (відбиток пальців, райдужна оболонка ока, голос, обличчя) та поведінкові (підпис, спосіб введення на клавіатурі). Зазвичай до біометричних маркерів ставляться такі вимоги [15]:

- унікальність для кожної людини;

- універсальність (наявність у всіх суб'єктів);

- стабільність у часі;

- легкість вимірювань;

- інваріантність до інших фізіологічних факторів (стрес, втома тощо).

Існують також додаткові вимоги, які не є обов'язковими, але додають істотну перевагу:

- стійкість до шахрайства (важко підробити);

- безперервний характер (завжди доступні для вимірювання);

- підтвердження життєдіяльності (притаманні тільки живим людям).

Класичні біометричні підходи діють за припущенням, що різні фізіологічні або поведінкові структури є індивідуальними та унікальними і майже не змінюються у часі. Науковий прогрес у галузі інформаційних технологій та побутової електроніки призвів до появи штучного інтелекту, портативних носійних пристроїв (англ. Wearables) та інтернету речей, що водночас зробило доцільним дослідження нових альтернативних біометричних методик. Відтак кінцевою метою є розроблення більш надійних, гнучких, зручних для користувачів та стійких до підробок біометричних систем.

Біосигнали можуть бути одним з найкращих варіантів альтернативних біометричних маркерів, оскільки вони містять важливу інформацію про психофізіологічний стан окремих органів і людини загалом. Така інформація важлива не тільки в медичній практиці для діагностики можливих захворювань, але широко застосовується і в інших сферах, таких як: афективна інформатика (моніторинг психоемоційного стану водіїв та операторів на критичних об'єктах інфраструктури, детектори брехні), реабілітаційна техніка (екзоскелети), взаємодія людина-машина (нейрокомп'ютерні інтерфейси) $[20,30]$. Як показано в $[11,28]$, біосигнали можуть бути використані у системах контролю доступу для ідентифікації людини на підставі іï фізіологічних параметрів.

ЕКГ-сигнал $\epsilon$ одним 3 найперспективніших для цього типу біометричних застосунків. Це пов'язано 3 низкою факторів, таких як: відносно високий рівень сигналу (порівняно 3 електроенцефалограмою), пері- 
одичний характер, легкість вимірювання (не вимагає стимуляційного обладнання, на відміну від фотоплетизмографії або біоімпедансометрії), наявність в будь-якій частині тіла (груди, шия, кінцівки, пальці). Ці фактори дають змогу виготовити апаратне забезпечення, яке відносно просте, дешеве і зручне для повсякденного використання $[1,8]$.

Загальною особливістю, що притаманна майже усім видам біосигналів, є мінливість у часі, зумовлена біологічними процесами всередині організму. 3 одного боку, це ускладнює підбір інформаційних параметрів, унікальних для конкретної людини, але з іншого - забезпечує вищу стійкість до шахрайства, оскільки такий біомаркер складніше підробити. Типовим явищем в обробленні біосигналів є промахи. Термін "промах" стосується тих фрагментів сигналу, які аномально відхиляються від сусідніх сегментів. Причини промахів можуть бути як зовнішніми (паразитне електромагнітне випромінювання, перехідні швидкоплинні процеси в електронних колах, тощо), так і внутрішніми (накладання 3 іншими типами біосигналів, наприклад, 3 електроміограмою чи диханням). Усунення впливу промахів є однією 3 найважливіших трансформацій у каналі оброблення сигналів біометричних систем на підставі ЕКГ [22]. Отже, важливо порівняти ефективність різних методів коригування промахів для ЕКГ-сигналів, за використання декількох поширених алгоритмів машинного навчання для ідентифікації.

\section{Викладення основного матеріалу}

Промахи в ЕКГ-сигналах. Як зазначено в попередньому розділі, на сигнал ЕКГ можуть впливати різні фактори, такі як шум м'язів, дихальні рухи, зміщення електродів тощо. Часто форма сигналу ЕКГ, що відповідає окремому скороченню серця, буває серйозно спотвореною порівняно 3 іншими суміжними сегментами $\mathrm{i}$ може розглядатися як аномалія або промах. Хорошим способом для розуміння специфіки промахів ЕКГсигналу є візуальна оцінка за допомогою накладання суміжних ЕКГ-сегментів. Для цього оригінальний сигнал розбивається на відтинки, що відповідають окремим скороченням серця 3 подальшим вирівнюванням по $R$ зубцю. Приклади промахів в ЕКГ-сигналі наведено на рис. 1.

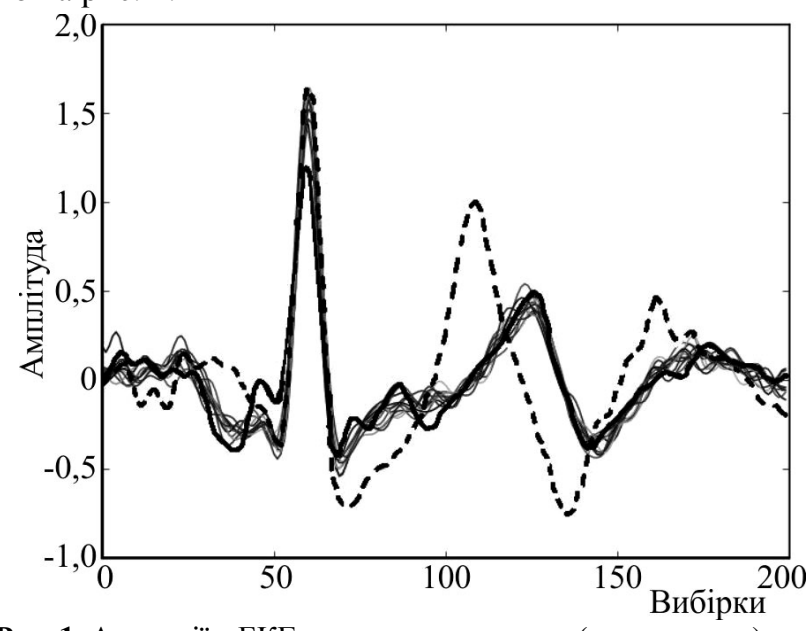

Рис. 1. Аномалії у ЕКГ-сегментах: невелика (жирна крива) та значна (пунктирна крива)

Як видно на рис. 1, промахи можна розділити на невеликі та значні. На практиці значні промахи ускладнюють генералізацію класифікатора (модель намагається вивчити аномальні варіації, а не зосереджується на незначних інформативних деталях). Перевага запропонованих підходів полягає в ефективності коригування промахів обох видів.

Виявлення та коригування промахів. Зазвичай, процедура оброблення промахів орієнтована на виявлення та відкидання аномальних сегментів. У цій роботі автори використовують коригування аномальних сегментів та подальше використання релевантних даних для навчання та валідації моделі. Основну ідею подано в роботах $[17,19]$. Такий підхід збільшує статистичну базу, що дуже важливо для наборів даних малого та середнього розміру. Окрім цього, система матиме вищу точність у повсякденному використанні, завдяки кращій генералізації та попередньому обробленні сегментів із промахами. Найбільшим недоліком цього підходу $€$ збільшення часу на опрацювання сигналу. Нижче наведено розроблені у попередніх роботах підходи до виявлення та коригування промахів (рис. 2).
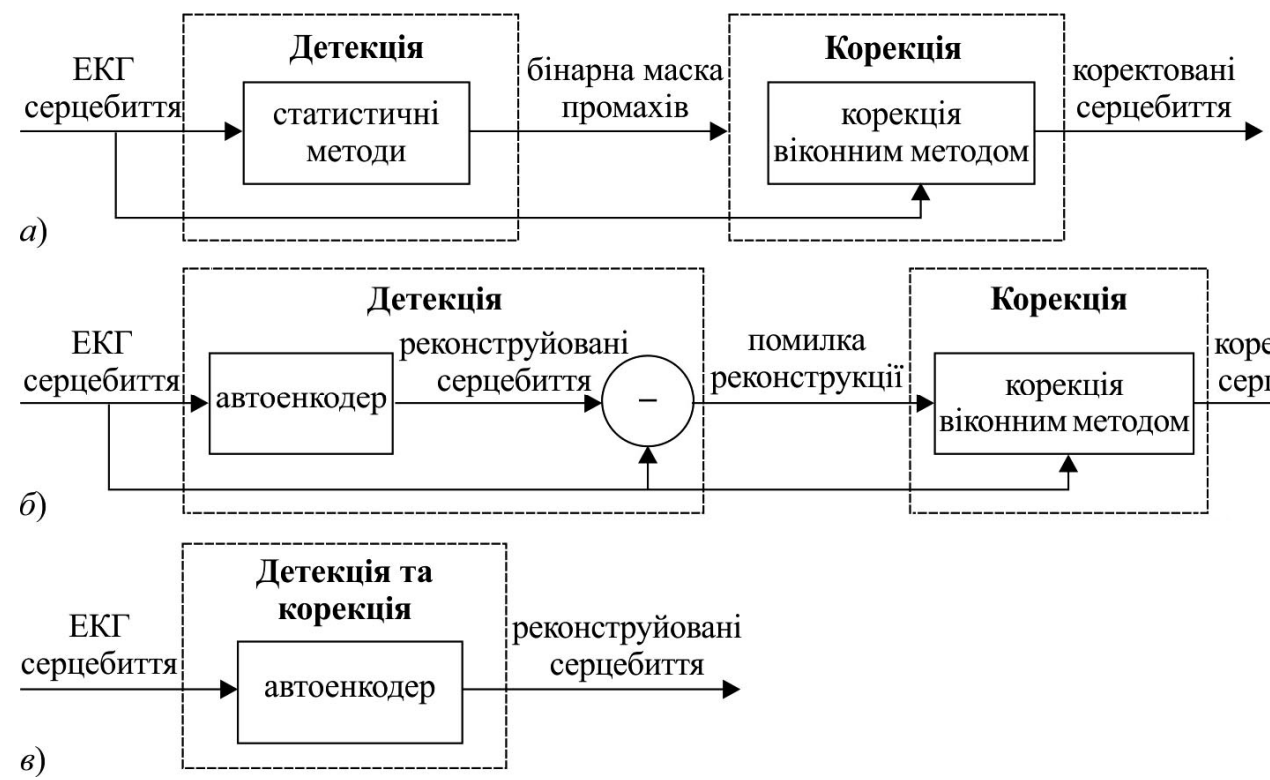

Рис. 2. Засоби виявлення та виправлення промахів на підставі: статистичного підходу з коригуванням ковзним вікном (а), підходу на підставі автоенкодера з коригуванням ковзним вікном (б), підходу на підставі коригування автоенкодером (в) 
Перший підхід заснований на ковзному вікні, яке обчислює евклідову відстань між зразками всередині вікна і статистичними характеристиками (середні значення для цього експерименту). Ідея цього методу [19] грунтується на припущенні, що аналіз розподілу зразків у кожному вікні дає змогу вказати та локалізувати короткочасні аномальні збурення ЕКГ-сигналу. Для цього розраховується відстань між поточними зразками (всередині вікна) та деякими статистичними характеристиками (середні значення). Якщо виявилося, що відстань перевищує певний поріг, всі зразки для поточного вікна розглядаються як промахи і замінюються на середні значення. Процедуру потрібно виконувати рекурсивно, поки для цього вікна не залишиться жодного промаху. Отже, статистичний підхід 3 коригуванням віконним методом можна розділити на два основні етапи:

1. Виявлення вікон із промахами, в межах якого відхилення навіть однієї вибірки перевищує визначений поріг.

2. Заміна цих вікон із промахами на еквівалентні вікна, отримані внаслідок усереднення відповідних сусідніх сегментів.

На першому етапі (виявлення промахів) визначається вектор середніх значень для кожного зразка

$$
\bar{x}(n)=\frac{1}{K} \sum_{k=1}^{K} x(k, n),
$$

де: $x(k, n)$ - елемент матриці ЕКГ-сигналу $X(K, N)$; $k \in 1 \div K$ - рядки відповідають номеру серцебиття; $n \in 1 \div N-$ колонки відповідають номеру вибірки всередині серцебиття.

Окрім цього, за формулою (2) обчислюється вектор стандартних відхилень:

$$
\operatorname{std}(n)=\frac{1}{K-1} \sqrt{\sum_{i=1}^{K} x(k, n)-\bar{x}(n)} .
$$

Далі середнє значення стандартного відхилення для матриці $X(K, N)$ можна обчислити як:

$$
\overline{s t d}=\frac{1}{N} \sum_{n=1}^{N} s t d(n) \text {. }
$$

На підставі обчислених вище величин і матриці ЕКГ-сигналу $X(K, N)$ обчислюється бінарна матриця промахів $O(K, N)$ :

$$
o(k, n)=\frac{|x(k, n)-x(n)|}{s t d}>\text { threshold },
$$

де $o(k, n)$ - елемент бінарної матриці $O(K, N)$, де кожне ненульове значення відповідає промаху.

На другому етапі, а саме - процедурі коригування промахів, проводиться таке перетворення:

$$
x(k, n: n+L)=\left\{\begin{array}{l}
\bar{x}(n: n+L), \\
\text { if anyino }(k, n: n+L)=1, \\
x(k: n+L), \\
\text { if anyino }(k, n: n+L)=0 .
\end{array}\right.
$$

де: $x(n: n+L)$ - усі усереднені вибірки всередині вікна довжини $L ; x(k, n: n+L)$ - усі вибірки серцебиття $k$, всередині вікна довжини $L ; o(k, n: n+L)$ - усі промахи серцебиття $k$, всередині вікна довжини $L$.

Насправді поріг і довжина вікна - це гіперпараметри алгоритму, значення яких вибираються емпірично. Як показано в роботі [20], головне завдання процедури ко- ригування промахів полягає у тому, щоб знайти оптимальні значення гіперпараметрів, які зможуть задовольнити всі випадки. Цей процес складно автоматизувати, тому він вимагає певного рівня інтуїції, що $є$ одним 3 основних недоліків описаного методу.

Альтернативний підхід полягає у тому, щоб для виявлення промахів використовувати алгоритми машинного навчання замість аналітичних виразів [17]. Для цього завдання існує декілька прийомів, але найперспективнішим є використання автоенкодерів [2, 4]. Автоенкодер - це окремий тип штучної нейронної мережі, для якої вектори вхідних і вихідних даних збігаються 3 деякою точністю (рис. 3).

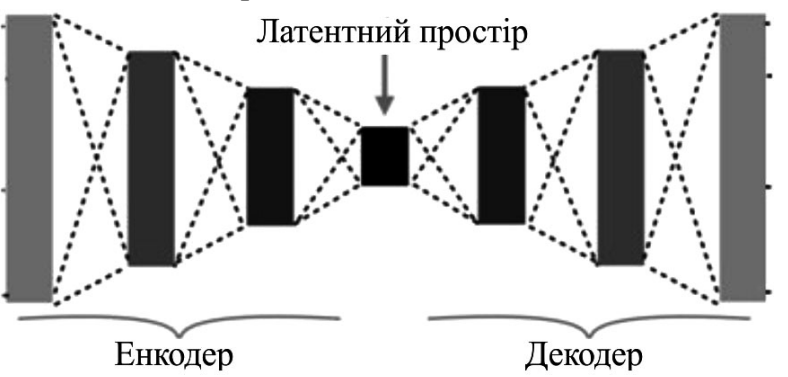

Рис. 3. Загальна архітектура автокодера

Формально роботу автоенкодера можна описати за допомогою функції:

$$
g=h(f(x))
$$

де: $f$ - функція енкодера; $g$ - функція декодера; $x$ - вхідний вектор.

1. Енкодер: це частина нейромережі, що стискає вхідні значення та подає їх у формі латентного простору ("коду") та може бути представлена функцією кодування $h=f(x)$.

2. Декодер: ця частина нейромережі має на меті реконструювати вхідні дані з латентного простору і може бути представлена функцією декодування $r=g(h)$.

Виконуючи цю процедуру ітеративно, модель знайде оптимальні параметри (ваги), які будуть зберігати реконструйовані значення близькими до вхідних, наскільки це можливо. На практиці цей підхід працює за рахунок того, що розмірність вектора в латентному просторі значно менша, ніж вхідного вектора в початковому просторі. Отже, кодується найважливіша, відтворювана інформація, тоді як шум та артефакти автоматично видаляються. Після декодування вихідний вектор схожий на вхідний, але в ньому вже майже відсутні викривлення та аномалії.

Сьогодні автоенкодери є дуже популярною сім'єю нейронних мереж у багатьох застосуваннях. Вони широко використовуються для нелінійної фільтрації та знешумлення даних, зменшення розмірності тощо.

Сутність запропонованого алгоритму коригування промахів полягає у такому:

1. Модель автоенкодера навчається на кожному окремому сегменті ЕКГ-сигналу, що відповідає окремому скороченню (удару) серцевого м'яза. У ходів навчання моделі підбираються ваги, які зможуть мінімізувати помилку реконструкції на всьому наборі даних.

2. Пропускаючи дані через модель автоенкодера та порівнюючи різницю між вхідним та реконструйованими ЕКГ-сигналом, визначаються потенційно аномальні вибірки.

3. Якщо аномальні вибірки розміщені послідовно в межах ковзного вікна, сегмент трактується як промах. 
4. Усі сегменти - промахи замінюються еталонними значеннями, використовуючи ту саму процедуру, що і в алгоритмі коригування промахів, описаному для першого підходу.

Насправді цей підхід також грунтується на коригуванні віконним методом, але замість статистичної детекції промахів використовується помилка реконструкції автоенкодера.

Третій підхід також грунтується на автоенкодері i запропонований у цій роботі вперше. Основна його відмінність від попередньої реалізації полягає у використанні реконструйованого сигналу для подальшої ідентифікації замість аналізу та оброблення помилки реконструкції. Отже, фаза детекції промахів не представлена як окрема трансформація, оскільки всі промахи будуть виправлені на етапі реконструкції вхідного сигналу автоенкодера. На відміну від двох попередніх підходів, цей алгоритм не потребує коригування віконним методом і повністю базується на автоенкодері.

Третій підхід має іще одну альтернативну реалізацію, в якій для формування реконструйованого сигналу без аномалій використовується інший вид алгоритмів генеративні адверсаріальні нейронні мережі GAN (англ. Generative Adversarial Networks). Суть методу полягає в тому, що системі, окрім власне автоенкодера, який намагається реконструювати сигнал у системі, присутня іще одна нейронна мережа - так званий дискримінатор. На вхід дискримінатору почергово у випадковому по- рядку подаються як реальні сегменти ЕКГ, так і результат реконструкції автоенкодера. Завдання дискримінатора у системі зводиться до того, щоб відрізняти (дискримінувати) реальні і згенеровані автоенкодером зразки. Відповідно автоенкодер генеруватиме більш реалістичні зразки ЕКГ-сигналу, без аномалій, що відповідно сприятиме кращій генералізації класифікатора і вищій надійності ідентифікації. Також варто зазначити, що дискримінатор бере участь тільки на етапі навчання автоенкодера. У разі функціонування системи в режимі ідентифікації бере участь тільки автоенкодер.

Опис біометричної системи. Загальну структуру розробленої біометричної системи подано на рис. $4 \mathrm{i}$ вона схожа на описану в роботі [34]. До складу біометричної системи ідентифікації входять такі компоненти:

- ланка вимірювання ЕКГ-сигналу;

- ланка цифрової обробки сигналу (ЦОС);

- ланка сегментації;

- вузол виявлення та коригування аномалій;

- вузол зменшення розмірності даних;

- вузол класифікації та ідентифікації.

Ланка вимірювання ЕКГ-сигналу складається із електродів та допоміжної електроніки, за допомогою яких вимірюється зміна різниці потенціалів пальців правої та лівої рук, що відображають роботу серця. Цей спосіб реєстрації електрокардіограми відповідає першому стандартному відведенню, яке використовують в медичній діагностиці.

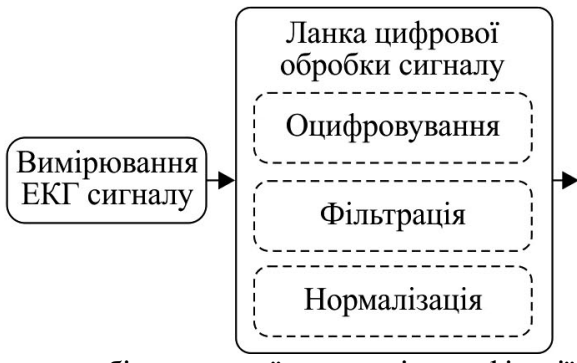

Рис. 4. Структурна схема біометричної системи ідентифікації

У ланці ЦОС виміряний сигнал оцифровується і піддається фільтрації та нормалізації за амплітудою. Оцифровані дані фільтруються двічі: низькочастотна фільтрація для видалення низькочастотних флуктуацій, зумовлених зміщенням чи диханням людини та високочастотна фільтрація для видалення шуму, наведень мережі і артефактів руху. Після цього ЕКГ-сигнал розбивається на окремі сегменти (в межах одного такту серцевого скорочення) і нормалізується по амплітуді до діапазону $[-1 ; 1]$. Нормалізовані сегменти піддаються процедурі коригування за допомогою алгоритмів, описаних у попередньому розділі.

У машинному навчанні для покращення продуктивності роботи класифікатора часто застосовують зменшення розмірності даних. У цьому дослідженні було вирішено використати метод головних компонент (Principle Component Analysis - PCA), як один із найпростіших, але ефективних, алгоритмів зменшення розмірності даних [16].

Класифікатор побудовано на підставі декількох поширених алгоритмів машинного навчання. У попередніх роботах $[17,19]$ ми використовували лінійний дискримінантний аналіз (LDA) як основний алгоритм для здійснення ідентифікації. У цій роботі ми пропонуємо розширити перелік класифікаторів, додавши підтримку методу опорних векторів (SVM) та методу k-найближчих сусідів (KNN) [7, 25].

Методика проведення експериментів. Експерименти проводили на різних конфігураціях біометричної системи: без процедури коригування промахів та за допомогою трьох різних методів коригування промахів описаних вище. Класифікатор і автоенкодер ініціалізуються випадковими вагами, тому кожен експеримент проводився кілька разів, а у статті представлені усереднені значення точності. Випадково у пропорції 0,7/0,3 електрокардіограми було розділено на набори для тренування та тестування. Результати експериментів наведено в таблиці.

У попередніх роботах експерименти проводили на наборі даних ECG-ID Physionet [32]. У цій роботі ми використовуватимемо самостійно зібрані дані [23]. Усі записи одержано за допомогою біомедичної системи, побудованої на підставі мікросхем eHealth та Arduino Uno [3, 9]. Детальніше процедуру вимірювання електрокардіограм описано у роботі [34].

На цей час оновлена версія Львівського біометричного набору даних (Lviv Biometric Dataset) містить понад 1400 записів для 95 різних осіб і іï розміщено у відкритому доступі [23]. Цей набір даних у 4,5 раза більший, ніж набір даних Physionet ECG-ID (близько 300 записів для 90 осіб), який використовувався в попередніх роботах. 
Таблиця. Продуктивність алгоритмів коригування промахів

\begin{tabular}{|c|c|c|c|c|c|c|}
\hline \multicolumn{2}{|c|}{$\begin{array}{c}\text { Алгоритми коригування } \\
\text { промахів }\end{array}$} & Без коригування & $\begin{array}{c}\text { Статистичний під- } \\
\text { хід } 3 \text { ковзним вік- } \\
\text { ном }\end{array}$ & $\begin{array}{c}\text { На підставі авто- } \\
\text { енкодера } 3 \text { ков- } \\
\text { зним вікном }\end{array}$ & $\begin{array}{c}\text { На підставі авто- } \\
\text { енкодера }\end{array}$ & $\begin{array}{c}\text { На підставі } \\
\text { GAN архітекту- } \\
\text { ри }\end{array}$ \\
\hline \multicolumn{2}{|c|}{ Час опрацювання, мс } & 0 & 6 & 830 & 800 & 800 \\
\hline \multirow{6}{*}{$\begin{array}{l}\text { похибка іден- } \\
\text { тифікації (\%) }\end{array}$} & LDA & 13.9 & 4.4 & 7.5 & 8.9 & 8.5 \\
\hline & SVM & 25.8 & 6.2 & 8.9 & 5.4 & 5.5 \\
\hline & KNN & 22.4 & 3.0 & 5.0 & 2.5 & 2.4 \\
\hline & PCA+LDA & 16.9 & 3.8 & 5.0 & 2.0 & 1.7 \\
\hline & $\mathrm{PCA}+\mathrm{SVM}$ & 30.2 & 6.0 & 8.3 & 5.2 & 5.2 \\
\hline & $\mathrm{PCA}+\mathrm{KNN}$ & 21.3 & 2.9 & 4.3 & 2.3 & 2.3 \\
\hline
\end{tabular}

Кожен 3 алгоритмів коригування має набір гіперпараметрів, котрі потребують налаштування, такі як довжина вікна коригування, поріг для вікна коригування та кількість шарів і нейронів для автоенкодера. Оптимальні значення гіперпараметрів було обрано в роботах [17, 19]. Отже, довжина вікна коригування дорівнює 5 вибірок, поріг вікна коригування для статистичного підходу дорівнює 0,5 та для підходу на підставі автоенкодера 0,9. Автоенкодер складається із 4 шарів по 100 нейронів із функцією активації ReLU.

Для порівняння алгоритмів коригування пропонуємо використовувати як метрики похибку ідентифікації та тривалість оброблення сигналу у вузлі детекції та коригування промахів. У табл. 1 наведено результати експериментів на тестовому наборі даних для кожної 3 описаних вище конфігурацій біометричної системи.

Обговорення результатів дослідження. Як показали результати експериментів, найменша похибка ідентифікації була в разі використання LDA класифікатора у поєднанні з РCA $(1,7 \%)$ або $\mathrm{KNN}$ класифікатора 3 PCA $(2,3 \%)$. В обох випадках було застосовано алгоритм коригування промахів на підставі автоенкодера. Недоліком цього методу коригування є відносно низька швидкість оброблення сигналу (майже одна секунда порівняно 3 кількома мілісекундами для статистичного підходу з коригуванням віконним методом). Найтривалішою стадією процесу ідентифікації $€$ вимірювання ЕКГ-сигналу, оскільки запис одного такту серцебиття займає від 0,5 до 1 секунди. Для надійної ідентифікації потрібно не менше 5-7 тактів, що потребує до 5 секунд. Отже, додавання алгоритму на підставі коригування автоенкодером збільшить загальну тривалість ідентифікації тільки на 20 \%, що не повинно бути критичним для більшості застосунків.

Однак важливо зауважити, що підхід на підставі коригування автоенкодером є затратним 3 погляду складності обчислень та споживання пам'яті, і отже, нетривіальним для реалізації, що робить статистичний підхід 3 коригуванням віконним методом більш привабливим для реалізації у простих інтерактивних застосунках.

\section{Висновок}

Біометрика - це галузь науки і техніки, яка займається ідентифікацією та автентифікацією людини за унікальними, властивими тільки їй біологічними маркерами. На сьогодні одним $з$ найперспективніших біомаркетів є сигнал електрокардіограми.

Однією з найбільших проблем в обробленні та аналізі біосигналів є так звані "промахи", тобто вибірки сигналу, які істотно відрізняються від сусідніх вибірок. Усунення їх впливу $є$ критичним завданням для розроблення надійних біометричних систем на підставі ЕКГ [22].

У попередніх роботах [17, 19] автори подали такі підходи коригування промахів: статистичний підхід 3 коригуванням віконним методом та підхід на підставі автоенкодера 3 коригуванням віконним методом. У цій роботі запропоновано новий підхід, що грунтується на використанні реконструйованого сигналу автоенкодера, що не потребує віконного коригування. Метою цієї роботи $\epsilon$ порівняння ефективності згаданих алгоритмів коригування промахів за допомогою таких показників: похибка ідентифікації та тривалість оброблення сигналу.

За результатами експериментів, поданих у розділі 5, навіть попри те, що підхід на підставі коригування автоенкодером більш витратний з погляду часу та споживання пам'яті, ніж статистичний підхід з коригуванням віконним методом, загальна тривалість ідентифікації буде збільшена тільки на $20 \%$, що не повинно бути критичним у більшості випадків. 3 іншого боку, підхід на підставі коригування автоенкодером дає змогу зменшити похибку ідентифікації до 2 \% (точність $98 \%$ ), тоді як статистичний підхід з коригуванням віконним методом забезпечує $2,9 \%$ (97,1 \% точності). Базова похибка ідентифікації становить близько $14 \%$ (похибка ідентифікації без застосування будь-яких алгоритмів коригування), тому у будь-якому разі алгоритми коригування промахів мають тенденцію до зменшення похибки ідентифікації в 4,8-7,0 разів, що робить обгрунтованим введення етапу коригування в канал біометричної ідентифікації на базі ЕКГ.

\section{References}

1. Albulbul, A. (2016). Evaluating Major Electrode Types for Idle Biological Signal Measurements for Modern Medical Technology. Bioengineering, 20(3), 1-10

2. Arden Dertat, Applied Deep Learning - Part 3: Autoencoders. Retrieved from: https://towardsdatascience.com/applied-deep-learning-part-3.

3. Arduino UNO \& Genuino UNO. (2019). Retrieved from: https://store.arduino.cc/arduino-uno-rev3.

4. Bengio, Y., Goodfellow, I., \& Courville, A. (2016). Deep learning. MIT press, $775 \mathrm{p}$.

5. Bernieri, G., Miciolino, E. E., Pascucci, F., \& Setola, R. (2017). Monitoring system reaction in cyberphysical testbed under cyberattacks. Computers \& Electrical Engineering, 59, 86-98

6. Birch, J. (2003). Benefit of legal metrology for the economy and society. A study for the International Committee of Legal Metrology. Retrieved from: https://www.oiml.org/en/files/pdf_e/e002-e03.pdf.

7. Bishop, C. M. (2006). Pattern Recognition and Machine Learning. In Information Science and Statistics. Springer: Singapore, $738 \mathrm{p}$.

8. Chi, Y. M., Wang, Y. T., Wang, Y., Maier, C., Jung, T. P., \& Cauwenberghs, G. (2012). Dry and Noncontact EEG Sensors for Mobile Brain - Computer Interfaces. IEEE Transactions on Neural Systems and Rehabilitation Engineering, 20(2), 228-235

9. e-Health Sensor Platform V2.0 for Arduino and Raspberry Pi. (2020). Retrieved from: https://www.cooking-hacks.com/documentation/tutorials/ehealth-biometric-sensor-platform-arduinoraspberry-pi-medical

10. Ferrero, A., \& Scotti, V. (2013). Forensic metrology: A new application field for measurement experts across techniques and ethics. IEEE Instrumentation \& Measurement Magazine, 16(1), 14-17 
11. Fratini, A., Sansone, M., Bifulco, P., \& Cesarel, M. (2015). Individual identification via electrocardiogram analysis. BioMed Eng OnLine, 14(78), 1-23

12. Glowacz, A. (2014). Diagnostics of Synchronous Motor Based on Analysis of Acoustic Signals with the use of Line Spectral Frequencies and K-nearest Neighbor Classifier. Archives of Acoustics, 39(2), 189-194

13. Glowacz, A., \& Glowacz, W. (2018). Vibration-based fault diagnosis of commutator motor. Shock and Vibration, 7(4), 60-64

14. Grzechca, D. (2011). Soft fault clustering in analog electronic circuits with the use of self organizing neural network. Metrol. Meas. Syst., 18(4), 555-568

15. Jain, A., Flynn, P., \& Ross, A. A. (2008). Handbook of Biometrics. Springer: $564 \mathrm{p}$.

16. Jolliffe, I. T. (2002). Principal Component Analysis, Series: Springer Series in Statistics, (2nd ed.), Springer, N-Y, XXIX, 487 p.

17. Karpinski, M., Khoma, V., Dudykevych, V., Khoma, Y., \& Sabodashko, D. (2018, September). Autoencoder Neural Networks for Outlier Correction in ECG-Based Biometric Identification. In: 2018 IEEE 4th International Symposium on Wireless Systems within the International Conferences on Intelligent Data Acquisition and Advanced Computing Systems (IDAACS-SWS). Lviv, Ukraine, $210-215$

18. Khoma, A., \& Zygarlicki, J. (2015). Surface topology reconstruction from the white light interferogram by means of Prony analysis. Metrol. Meas. Syst., 22(1), 479-490

19. Khoma, V., Pelc, M., Khoma, Y., \& Sabodashko, D. (2018). Outlier Correction in ECG-Based Human Identification. In: Hunek W., Paszkiel S. (Eds.) Biomedical Engineering and Neuroscience. BCI 2018. Advances in Intelligent Systems and Computing, $720,11-22$

20. Kołodziej, M., Tarnowski, P., Majkowski, A., \& Rak, R. J. (2019). Electrodermal activity measurements for detection of emotional arousal. Bull. Pol. Ac.: Tech. Sci., 67(4), 813-826

21. Kurzynski, M., Ryba, P., Markowski, M., \& Wozniak, M. (2010). Medical Telemetry System for Monitoring and Localization of Patients - Functional Model and Algorithms for Biosignals Processing. INTL Journal of Electronics and Telecommunications, 56(4), 445-450

22. Lourenco, A., Plácido da Silva, H., \& Carreiras, C. (2013). Outlier detection in non-intrusive ECG biometric system. In International
Conference Image Analysis and Recognition. Berlin, Heidelberg, 43-52

23. Lviv Biometric Data Set. (2018). Retrieved from: https://github.com/YuriyKhoma/Lviv-Biometric-Data-Set.

24. Moed, H. F., Glänzel, W., \& Schmoch, U. (2004). Handbook of quantitative science and technology research. Netherlands: Kluwer Academic, Springer, $785 \mathrm{p}$.

25. Pedregosa, F., et al. (2011). Scikit-learn: Machine Learning in Python. Journal of Machine Learning Research, 12, 2825-2830

26. Pelc, M., Khoma, Y., \& Khoma, V. (2019). ECG Signal as Robust and Reliable Biometric Marker: Datasets and Algorithms Comparison. Sensors, 19(10), 2350, 1-8

27. Pohrebennyk, V., Mitryasova, O., Dzhumelia, E., \& Kochanek, A. (2017). Evaluation of surface water quality using water quality indices in mining and chemical industry. In the 17th International Multidisciplinary Scientific Geoconference SGEM 2017, Albena, Bulgaria, Vol. 17, 425-432

28. Rangaraj, M. R. (2001). Biomedical signal analysis. A case-study approach. Wiley-IEEE Press: $555 \mathrm{p}$.

29. Shu, C., \& Kochan, O. (2013). Method of thermocouples self verification on operation place. Sensors \& Transducers, 160(12), $55-61$

30. Singh, R. R., Conjeti, S., \& Banerjee, R. (2013). Comparative evaluation of neural network classifiers for stress level analysis of automotive drivers using physiological signals. Biomedical Signal Processing and Control, 8, 740-744

31. Tadeusiewicz, R. (2015). Neural networks in mining sciences general overview and some representative examples. Arch. Min. Sci., 60(4), 971-984

32. The ECG-ID Database. (2018). Retrieved from: https://physionet.org/physiobank/database/ecgiddb/

33. Vasylkiv, N., Kochan, O., Kochan, R., \& Chyrka, M. (2009). The control system of the profile of temperature field. In: 2009 IEEE International Workshop on Intelligent Data Acquisition and Advanced Computing Systems: Technology and Applications. IEEE, 201-206

34. Wieclaw, L., Khoma, Y., Fałat, P., Sabodashko, D., \& Herasymenko, V. (2017). Biometrie identification from raw ECG signal using deep learning techniques. In: 2017 9th IEEE International Conference on Intelligent Data Acquisition and Advanced Computing Systems: Technology and Applications (IDAACS). Bucharest, Romania, 1, 129-133

Yu. V. Khoma1, V. V. Khoma ${ }^{1,2}$, Su Jun', O. V. Kochan ${ }^{1,3}$

${ }^{l}$ Lviv Polytechnic National University, Lviv, Ukraine ${ }^{2}$ Opole University of Technology, Opole, Poland

${ }^{3}$ Hubei University of Technology, Hubei, China

\section{ANALYSIS OF EFFICIENCY OF THE OUTLIERS CORRECTION METHODS FOR SYSTEMS OF BIOMETRIC IDENTIFICATION BASED ON ELECTROCARDIOGRAM}

The purpose of this work is to compare the efficiency of different outlier correction methods in biometric identification systems. The main idea is to reveal segments of the ECG signal with outliers, and instead of their removal from the identification process, apply the correction procedure on them. This results in an increased amount of data and a more solid statistical base for system training and calibration. Three different methods of outlier corrections were compared in this paper. The first method is based on the estimation of the samples deviation from a certain nominal value above some threshold. Only a part that is represented within a sliding window is being analyzed, and not the whole signal immediately. Two other methods are based on the idea of using autoencoders which is a particular implementation of the artificial neural networks. The main difference between the two autoencoder-based methods is the following: one method is using the sliding window that allows defining correction criteria directly, while for the other method correction criteria are defined automatically by a system on the training stage. In addition, the paper has described the structure of biometric identification systems based on the signal of a human electrocardiogram. The key structural components of the system are analog measuring circuit, ADC and several digital functional blocks for signal processing and analysis. These blocks can be implemented on various computing platforms such as a microcontroller, PC or cloud. These digital blocks represent a set of transformations such as low and high pass filtering, R-peaks detection in electrocardiogram signal, heartbeat segmentation, magnitude normalization, anomaly correction, dimensionality reduction, and classification. Experiments were conducted on self-collected dataset LBDS (Lviv Biometric Dataset). At the time of paper preparation, the dataset contained over 1400 records of 95 individuals. The basic identification error without any outlier correction is about $14 \%$. After outlier correction was applied - identification error was decreased to $2.0 \%$ for autoencoder-based algorithms and to $2.9 \%$ for a statistical-based method. The best results were achieved for LDA classifier combined with PCA compression (1.7\%), and for KNN classifier without PCA compression (2.3\%). Yet, adding outlier correction to the process of biometric identification results in a certain increase in overall processing time (about $20 \%$ ), that however, is not critical for most of the real-world applications.

Keywords: biometrics; human identification; ECG signal; autoencoders; machine learning; anomaly detection. 